\title{
REGIONAL INTEGRATION AND FOREIGN DIRECT INVESTMENT
}

\author{
Magnus Blomström \\ Ari Kokko
}

Working Paper 6019

\author{
NATIONAL BUREAU OF ECONOMIC RESEARCH \\ 1050 Massachusetts Avenue \\ Cambridge, MA 02138 \\ April 1997
}

This paper was commissioned by the World Bank and is part of the Regionalism and Development Research Project. Thanks are due to Maurice Schiff and Alan Winters at the World Bank and Robert Lipsey at the NBER for useful discussions and comments on an earlier draft of the paper. We have also benefited from detailed discussions and joint work on related topics with Steven Globerman. This paper is part of NBER's research program in International Trade and Investment. Any opinions expressed are those of the authors and not those of the National Bureau of Economic Research.

(C) 1997 by Magnus Blomström and Ari Kokko. All rights reserved. Short sections of text, not to exceed two paragraphs, may be quoted without explicit permission provided that full credit, including $(\mathcal{C}$ notice, is given to the source. 
Regional Integration and Foreign Direct Investment

Magnus Blomström and Ari Kokko

NBER Working Paper No. 6019

April 1997

JEL Nos. F15, F23

International Trade and Investment

\begin{abstract}
This paper deals with the investment effects of regional integration agreements and discusses how such arrangements may affect inward and outward foreign direct investment flows in the integrating region. After setting up a conceptual framework for the analysis, we provide three studies focusing on different kinds of regional integration: North-North integration (Canada joining CUSFTA), North-South integration (Mexico's accession to NAFTA), and South-South integration (MERCOSUR). The main conclusion of the study is that the responses to an integration agreement largely depend on the environmental change brought about by the agreement and the locational advantages of the participating countries and industries. Moreover, the findings suggest that the most positive impact on FDI has occurred when regional integration agreements have coincided with domestic liberalization and macroeconomic stabilization in the member countries.
\end{abstract}

Magnus Blomström

Stockholm School of Economics

PO Box 6501

11383 Stockholm

SWEDEN

and NBER

gmb@hhs.se
Ari Kokko

Stockholm School of Economics

PO Box 6501

11383 Stockholm

SWEDEN

gak@hhs.se 


\title{
Regional Integration and Foreign Direct Investment
}

\author{
Magnus Blomström and Ari Kokko
}

\section{Introduction}

Recent years have witnessed a deepening and widening of European integration and a proliferation of new regional integration agreements (RIAs) throughout the world, with acronyms such as APEC, EU, MERCOSUR, and NAFTA attracting increasing attention. Although some integration agreements have been motivated by political considerations, it is clear that economics is generally the driving force: countries enter into RIAs because integration promises various economic benefits. In the short run, integration is expected to stimulate intra-regional trade and investment; in the longer run, it is hoped that the combination of larger markets, tougher competition, more efficient resource allocation, and various positive externalities will raise the growth rates of the participating economies. This paper focuses on the investment effects of RIAs, and discusses how such arrangements may affect foreign direct investment (FDI) flows in the integrating region. With foreign direct investment, we refer to foreign ownership of a controlling share of a firm operating in a country's domestic market: FDI flows refer to changes in the foreign ownership of production factors.

The perhaps most serious challenge facing a study of the relation between regional integration and foreign direct investment is the multi-dimensional character of the issue. There is reason to believe that effects will vary between different integration agreements, and between countries and industries participating in any specific agreement. For instance, the degree of integration at the outset, and the significance and nature of the changes brought about

\footnotetext{
* This paper was commissioned by the World Bank and is part of the Regionalism and Development Research Project. Thanks are due to Maurice Schiff and Alan Winters at the World Bank and Robert Lipsey at the NBER for useful discussions and comments on an earlier draft of the paper. We have also benefited from detailed discussions and joint work on related topics with Steven Globerman. The standard disclaimer applies.
} 
by the RIA, will matter for the outcome. The patterns of trade and investment at the outset will determine how much adjustment is necessary after the agreement. Countries where outward FDI flows are initially very large are not likely to be affected the same way as countries where inflows of FDI are dominant. Integration between developed countries may differ from integration between developing countries or agreements between countries at different levels of development, depending on how competitive and complementary the economies are. For these reasons, we present a simple conceptual framework that provides a rough indication of what to expect from any specific RIA. Moreover, we cover several different examples of regional integration in the empirical part of the paper.

The paper is organized as follows. The next section discusses how regional integration can potentially affect investment patterns among countries, and presents an organizational template for examining the relation between RIAs and FDI. Section 3 reviews some earlier empirical studies of the investment impact of regional integration, with focus on evidence from the European Community, and presents three case studies focusing on different kinds of regional integration: North-North integration (Canada joining CUSFTA), North-South integration (Mexico's accession to NAFTA), and South-South integration (MERCOSUR). Section 4 provides a brief summary and some tentative conclusions.

\section{Regional Integration Agreements and FDI: Some Theoretical Considerations}

The term regional economic integration typically refers to reductions of regional trade barriers and investment restrictions. To identify and assess some theoretical linkages between RIAs and incentives to undertake FDI, it is therefore convenient to structure the discussion along these two dimensions of integration. Hence, we begin by discussing effects of trade liberalization, and distinguish between the impact on FDI that is mainly a response to trade barriers, and FDI that is primarily motivated by the need to internalize firm-specific intangible assets that cannot be 
traded efficiently in arm's-length markets. We go on to consider the impact of special investment provisions and other institutional changes that are sometimes connected to integration agreements. The focus in this discussion lies on static effects: the possible dynamic effects of regional integration on investment flows are discussed separately. Finally, we suggest a template for classifying entire countries and specific sectors according to the expected impact on investments. $^{1}$

\subsection{Effects of Trade Liberalization: Tariff-jumping and Internalization}

The early theoretical and empirical literature on foreign investment tended to regard trade and capital movements as substitutable modes of serving foreign markets. ${ }^{2}$ This view of the relationship between trade and factor mobility suggests that tariff barriers could motivate importsubstituting FDI, and that general tariff reductions would reduce FDI flows or even stimulate a "repatriation" of foreign-owned assets to the home countries of MNCs. However, although much FDI is motivated by tariff-jumping arguments, there is a clear emphasis in more recent literature on exploitation of intangible assets as the major motive for foreign investment (see Caves 1996 for a review). In order to compete successfully in a foreign market - where local firms have superior knowledge of the local market, consumer preferences, and business practices - the internationally oriented firm must possess some firm-specific intangible asset, such as technological and marketing expertise, that gives it a competitive edge. The effective exploitation of these assets sometimes requires firms to "internalize" their international

\footnotetext{
${ }^{1}$ It should be noted already at the outset that the discussion will not address the welfare effects of changes in investment flows. Although the underlying assumption is that increased FDI flows are beneficial to growth and development in the integrating region, it should be recognized that the welfare effects may in fact be negative if the RIA worsens the allocation of resources or adds new distortions, e.g. in the form of higher average protection of the regional market. For a classic reference, see Brecher and Díaz-Alejandro (1977). In addition, the welfare effects on the rest of the world may well be negative if the RIA diverts investment from other countries to the region in question.

${ }^{2}$ See e.g. Mundell (1957). Note, however, that these authors, writing in the Heckscher-Ohlin tradition, seldom refer specifically to foreign direct investment: the strict distinction between FDI and foreign portfolio investment did not become essential until it was recognized that the exploitation of firm-specific intangible assets is a major motive for FDI, whereas portfolio investment is mainly motivated by international differences in capital yields.
} 
operations by establishing foreign affiliates, since other modes of international business, including exports and licensing of technology to foreign firms, carry relatively high transactions costs (Buckley and Casson 1976; Dunning 1977). Some FDI can therefore be expected to occur even when there are no formal trade barriers between countries.

These two views of the motives for FDI give partly contradictory predictions regarding the effects of regional integration, particularly for intra-regional investment flows. Regarding tariff-jumping FDI, we would primarily expect reduced investment flows because trade liberalization makes exporting from the home country relatively more attractive than FDI as a way to serve the regional market. ${ }^{3}$ However, regional integration would not create incentives to reduce investment or repatriate capital for projects that were primarily undertaken to internalize the exploitation of intangible assets. In fact, the reduction of regional trade barriers could instead stimulate overall FDI flows among the relevant trading partners by enabling MNCs to operate more efficiently across international borders. This argument applies in particular for vertically integrated FDI, where the operations of the MNC's different affiliates are specialized according to the locational advantages of the host country, and where a predictable and liberal trade environment is a prerequisite for the international division of labor at the firm level. Hence, the static effects on intra-regional FDI flows are subject to partially off-setting influences, and the net impact on any specific RIA or individual member country would tend to be determined by the structure of and motives for pre-existing investment. A reasonable generalization, however, is that countries with low initial trade restrictions are more likely to benefit from increased intra-regional FDI flows as trade barriers

\footnotetext{
${ }^{3}$ To the extent that regional integration results in trade creation, it may be necessary to temper this conclusion somewhat - intra-regional FDI in some member countries might well increase in response to changes in the regional production structure- but the general prediction would still be a reduction of intra-regional trade flows. The extent of these cross-border investment flows of course depends on the initial situation and the relative strength of the firms in the different member countries. This potential impact on intra-regional FDI flows has been termed "investment diversion" by Kindleberger (1966).
} 
are reduced, since they are not very likely to host import-substituting FDI projects that might be withdrawn.

Turning to inter-regional FDI flows, both the tariff-jumping and internalization models suggests increased investment flows. The inflows of FDI from "outsiders" into the region could obviously go up if the average level of protection increases as a result of the RIAs, or if the establishment of a RIA raises fears about future protection (as in the debate on "Fortress Europe"). The inflows of foreign capital would also increase if the volume of incoming FDI was initially restricted by the limited size of the individual national markets. Contrary to the national markets, the integrated "common" market may be large enough to bear the fixed costs for the establishment of new foreign affiliates. This surge of inward FDI would probably not be evenly distributed, but rather concentrated to the geographical areas with the strongest locational advantages. In addition, Kindleberger (1966) has pointed to "investment creation" as a likely response to the trade diversion brought about by RIAs. The term refers to the strategic investment responses by outside firms who lose export markets when their former customers turn to suppliers based in the region, because regional trade is not obstructed by trade barriers. ${ }^{4}$

The potential effects of RIA on outflows of FDI from the integrating region are rarely discussed in formal models. This is mainly related to the simplifying assumption that nothing happens with trade barriers in the rest of the world. However, some changes in outward FDI are feasible even when trade policies in the rest of the world remain unchanged. For instance, it is possible that a firm's capacity to undertake new FDI projects is restricted by its administrative capability or the availability of investment capital (Stevens and Lipsey 1992). In that case, it is

\footnotetext{
${ }^{4}$ It is also possible to picture situations where RIAs could cause a reduction of FDI from outside the region. Specifically, if the initial stock of outside FDI consists of horizontally organized affiliates in several or all of the countries in the region, it is not likely that this structure would be optimal after the establishment of the RIA. A possible response to integration could then be a rationalization of the network of affiliates, so that the entire region could be supplied from a smaller number of affiliates located in the member countries with the most favorable economic conditions. In this case - which is similar to Kindleberger's (1966) investment diversion case - some countries could experience disinvestments as foreign MNCs concentrate their regional operations in other member countries. On balance, however, it appears that the arguments in favor of increased FDI inflows from outside the RIA are stronger.
} 
likely that FDI within and outside the region are substitutes. To the extent that integration reduces intra-regional FDI, it may therefore increase the scope for outflows of FDI from the integrating area to other regions. Yet, this impact is not likely to be very strong, and it is reasonable to expect that the trade liberalization element of RIAs results in a net increase in the inflows of FDI to the region. However, intra-regional FDI is subject to contradictory influences, as noted above, and we are not able to say much about the investment effects on individual countries - investment can be expected to cluster to those parts of the RIA where the investment environment is most favorable, and some countries may therefore be left with less FDI than before.

\subsection{Explicit Investment Provisions and Other Influences}

To the extent that RIAs also liberalize capital flows, an additional stimulus is provided to the FDI process. Capital flows can be liberalized in several ways. Most directly, restrictions on inward foreign direct investment might be reduced or eliminated. Inward FDI will also presumably be encouraged by "national treatment" provisions ensuring that foreign investors are treated no less favorably than domestic investors. Obviously, the practical relevance of such provisions depends on the scope and magnitude of pre-existing barriers to inward FDI, as well as the extent and nature of host government discrimination against foreign investors. Explicit dispute resolution mechanisms are also featured in many integration agreements. To the extent that such mechanisms are effective, they should reduce trade and investment disputes between the participating nations and encourage FDI. ${ }^{5}$

Inward FDI could also be stimulated by the elimination of trade-related investment measures (TRIMs), such as requirements for foreign affiliates to satisfy specific export targets, and by the presence of strong investor property rights which reduce the risk of direct or indirect

\footnotetext{
${ }^{5}$ To the extent that potential trade disputes act as non-tariff barriers to trade, it is also possible that these mechanisms discourage some "tariff-jumping" FDI.
} 
expropriation. Both types of initiatives may be institutionalized in RIAs. In this context, it is possible that a significant effect of some RIAs may be that they "lock in" economic reforms in the participating countries. By raising reform decision from the national to the international level, the agreements may create a more predictable policy environment for foreign investors, who might otherwise fear that purely national reform efforts are temporary and that various kinds of restrictions may be reintroduced when the political regime changes. These effects are likely to be most important in agreements involving developing countries, where political risk is often considered to limit FDI inflows. Moreover, to the extent that "market forces" become a stronger influence on capital investment decisions compared to political risk, international differences in factor endowments should become stronger influences on investment location decisions. This strengthens the tendency for FDI to be concentrated to the most attractive investment locations in the integrating area.

\subsection{Dynamic Effects of Regional Integration}

In addition to the static effects discussed above, it is possible that the establishment of RIAs also generates various dynamic effects that affect FDI flows. For instance, analyses of the economic impact of the European Single Market have argued that this specific integration process has led to significant efficiency benefits that will raise the participating countries' growth rates over the medium or long term. These dynamic benefits might increase the attractiveness of the integrated region as a location for domestic as well as foreign investment. The higher growth rates may be temporary, lasting while the economies adjust to the higher real income that comes about because of tougher competition and more efficient allocation of resources in the common market (see e.g. Emerson et al. 1989). It is also possible that there are permanent growth effects that occur as the initial gains in efficiency and output raise factor rewards and generate new savings and investments that contribute further to output growth (Baldwin 1989). However, the exact 
links between regional integration and dynamic growth effects are not well specified, and it is not uncommon that analyses and empirical estimates of dynamic benefits are considered vague or speculative (Smith 1992).

In many instances, FDI may actually be an essential catalyst for these dynamic benefits. Some of the improvements in economic efficiency associated with increased specialization, exploitation of scale economies, and greater geographical concentration of individual economic activities are likely to be driven by inter and intra-regional FDI. Increased FDI flows are also important forces behind the heavier competitive pressure that is expected to encourage local producers to adopt efficiency-enhancing strategies, such as rationalizing plant capacity or reducing slack in the production process (Smith and Venables 1989). In addition, it is likely that FDI will stimulate technology transfer and diffusion, both directly and through spillovers to local firms (see Blomström and Kokko 1997).

Furthermore, if regional integration creates a larger market, it is also conceivable that some dynamic effects occur because regional integration influences various firm characteristics, such as the stock of intangible firm-specific assets that facilitate FDI. A larger market may simply allow some firms to grow larger and stronger than what would have been possible in individual national markets. Alternatively, integration may motivate firms to seek strategic alliances or merge with former competitors in order to manage in the more competitive environment that is created when intra-regional trade barriers are removed. As firms become larger, they may be able to invest more in R\&D and marketing, which may lead to the creation of new intangible assets that stimulate new FDI, within as well as outside their own region.

Including this kind of dynamic considerations into the analysis, it appears clear that there is a potential for significantly stronger effects on FDI than what static models imply. The main impact of dynamic benefits of integration is to make the integrating region a more attractive 
investment location, which should stimulate intra-regional FDI flows as well as inflows from the rest of the world.

\subsection{Synthesis of the Discussion}

Clearly, some FDI has been, and continues to be, motivated primarily by the desire to get behind trade barriers. Other FDI is motivated by foreign investors seeking to exploit input or output markets located abroad in activities where operating a foreign affiliate is the most efficient governance structure. In the discussion above, we have noted that regional integration is not likely to have the same impact on all types of FDI. For any individual country, the overall impact on investment will therefore reflect potentially offsetting influences. However, a reasonable generalization is that regional integration should enhance the attractiveness of investing in the region as a whole by creating a larger common market and contributing to improved overall efficiency and higher income levels in that market. The magnitude of the changes in investment will be related to the significance and nature of the trade and investment liberalization initiatives embodied in the RIA.

In addition to differences between RIAs, there are several reasons why the impact on investment decisions may vary across countries and industries. For instance, countries characterized by relatively unprotected and efficient domestic markets prior to regional integration are likely to enjoy the strongest increases in foreign as well as domestic investment. The reason is that countries with low trade barriers are not very likely to host import-substituting foreign investment that might be withdrawn or diverted to other locations as a result of regional integration. The ex ante structure of trade and investment flows is another determinant of the country and industry specific responses to RIAs. Countries and industries that are already closely linked to their RIA partners before the formal agreements - due to geography, historical 
conditions, or other reasons - are likely to face smaller changes than countries and industries with limited initial contacts with the other participants in the RIA.

In addition to the distinctions we have made regarding the motives for FDI, it may therefore be useful to specify a summary framework relating trade and investment liberalization initiatives to country and industry characteristics. Figure 1 provides an organizational template for thinking about the FDI process in the context of regional integration. The attribute labeled environmental change summarizes the degree to which trade and investment flows are liberalized by the integration agreements in question. This depends both on the nature of the specific agreement and the initial institutional environment in the region. As one moves down the rows of Figure 1, the degree of liberalization is considered to be "weaker". The attribute labeled locational advantage summarizes the degree to which it is advantageous from a profitability standpoint to locate an economic activity in a particular location. This characteristic refers to the availability and cost of various production factors as well as the country's geographic location with respect to major consumer markets and the general macroeconomic environment. As one moves across the columns (from left to right) in Figure 1, the locational advantages of a particular country - in relation to other members in the RIA and the rest of the world - are presumed to be weaker. Identifying the position of a specific country or industry in Figure 1, we will have a starting hypothesis for the investment impact of regional integration. More detailed predictions regarding FDI flows must, of course, also take into account trade and investment patterns prior to integration, the motives for pre-existing FDI, the competitive strength of domestic versus foreign firms, and so forth. 
FIGURE 1. Classification Dimensions

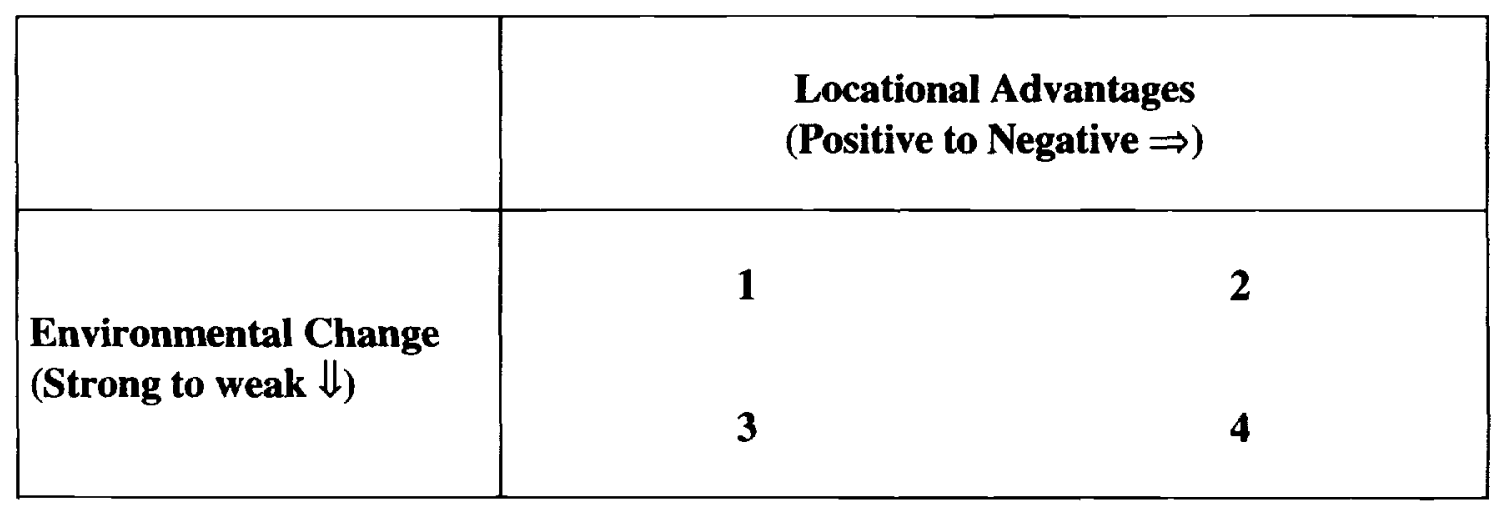

Source: Globerman and Schwindt (1996).

The most pronounced positive impact on investment would presumably be experienced by those economic sectors falling into area 1 . These activities experience the strongest degree of integration, and the country in question enjoys a strong locational advantage. Hence, for reasons noted earlier, one would anticipate relatively strong, positive capital flows from both foreign and domestic investors in these sectors. In area 3 , the hypothesized impact on domestic investment is weaker, albeit still positive. Area 3 contains those economic activities for which the country in question has a strong locational advantage, but for which the impact of the integration agreement is relatively weak. Economic integration between OECD countries, where the formal and informal barriers to trade and investment are relatively low already at the outset, can be expected to provide many examples of industries falling into this category.

Moving to area 2, the expected impact on inward FDI is negative and the potential for actual disinvestment increases. Specifically, the activities in area 2 are strongly affected by the integration agreement, but the country in question suffers locational disadvantages in these sectors. Many countries and industries where the bulk of existing FDI has been established in order to avoid trade barriers would be classified in this area. Finally, we hypothesize that the impact of integration on activities in area 4 are likely to be small. While the country or industry 
in question suffers a locational disadvantage in terms of the activities in area 4 , the impacts of the integration agreement on the overall economic environment are also quite weak. In other words, area 4 contains activities where investment decisions are not likely to be affected by the RIA, either because the sector in question is excluded from the agreement (such as agriculture in the EFTA or EEA agreements) or because the market is too small to attract the attention of foreign competitors.

\section{Empirical Studies of Regional Integration and FDI}

In the theoretical discussion, we concluded that it is difficult to make general predictions regarding the results of RIAs on foreign direct investment decisions, but that identifying the position of a specific country or industry in Figure 1 would provide a rough first hypothesis. The strongest positive effects on FDI are likely to occur in countries and industries where the integration agreement result in significant environmental change, and where we find some location advantages with respect to the other members of the RIA or the rest of the world.

In this section, we will review the empirical evidence on the investment effects of RIAs. To cover as many as different outcomes as possible, we have chosen to summarize some earlier empirical studies of the impact of European integration, and to examine three more recent cases of regional integration:

- North-North integration, as illustrated by the impact of the CUSFTA on Canada,

- North-South integration, focusing on Mexican participation in the NAFTA, and

- South-South integration, exemplified by the establishment of the MERCOSUR. 


\subsection{The Early Evidence}

Earlier work on regional integration and foreign direct investment have dealt mainly with the effects of European integration on the size and structure of the activities of MNCs. ${ }^{6}$ The period following the formation of the European Community coincided with a considerable inflow of US direct investment, and several studies from the 1960s and 1970s asked to what extent this was motivated by the European integration process (see Yannopoulos 1990 for a survey of the literature). The general conclusion of the debate was that the Common Market had attracted United States investment which might otherwise have been located in other European countries. Thus, the formation of the EC seems to have influenced the locational pattern of US direct investment abroad and lured US firms to increase their activities in the European Community. This empirical result is well in line with the theoretical hypotheses regarding the general effects of RIAs on inter-regional FDI flows discussed above: economic integration is likely to make the region a more attractive investment location for outside investors.

Studies of later stages in European integration have been more mixed in their findings about the effects on inter-regional foreign direct investment. For example, Dunning (1992), claims that the challenges of 1992 have led to a revitalization of US investment in the EC, while Lipsey (1990) concluded that the changes in the location of fixed investment by US MNCs were relatively small up through 1989 . The upsurge in Japanese investment in Europe has also attracted much attention, and the conclusion seems to be that those investments have increased as a consequence of the 1992 program, in response to both the opportunities and threats created by the integration process (see e.g. Thomsen and Nicolaides, 1991 and Balasubramanyam and Greenaway, 1992).

\footnotetext{
${ }^{6}$ Some exceptions to the European focus are early studies of Latin American integration, including Behrman's (1972) study of LAFTA, Myltelka's (1979) study of the Andean Group, and Bulmer-Thomas'(1982) study of The Central American Common Market.
} 
Studies of the impact of economic integration on intra-regional investment are more rare and generally constrained by data shortages. Some relatively crude studies by Franko (1976) and Pelkmans (1984), focusing on the changes in the number of foreign manufacturing subsidiaries of EC-firms established in other Community countries, found that European integration coincided with a period of clear shifts in the location of production of multinationals of EC parentage. In other words, these studies found signs of "investment diversion" in the Kindleberger sense. A similar picture is suggested in a later study by Molle and Morsink (1991), based on FDI flows between EC countries during the period 1975-1983. The study suggests that intra-EC trade and intra-EC investment are complementary to each other, but only above a certain level of trade intensity.

Most of the literature linking RIAs to foreign direct investment focuses on investment effects for the region as a whole. Substantially less attention has been paid to the impact of RIAs on the foreign direct investment outcomes for individual countries within the region. The few earlier works focusing on individual countries include studies of the UK (e.g. Mayes, 1983 and Grant, 1983) and Ireland (O'Farrell, 1983). The results from these studies are mixed. While no investment effects were found in the case of the UK, Ireland's membership of the EC stimulated direct investment from both EC and non-EC sources. One possible explanation could be that many foreign investors (particularly US firms) had entered the relatively open UK market already during the 1950s and 1960s, before the country's accession to the EC, so that little additional investment was necessary to respond to the new situation. In other words, the UK experience might illustrate a case that would be classified in area 3 of Figure 1. Ireland, by contrast, was not any major location for foreign investment prior to EC membership, and integration provided good opportunities for exploiting the country's locational advantages - this would be an example where area 1 dominates. Winters (1996) notes another distinction between Spain and Portugal, on the one hand, and Greece, on the 
other hand. Spain and Portugal benefited from significant increases in inward FDI as a result of EC membership, but Greece did not, largely because the country's macroeconomic policies did not provide an attractive environment for foreign investors. Hence, while Spain and Portugal can be classified as area 1 cases, Greece may illustrate area 2: weak locational advantages obstructed the potentially beneficial investment responses to Greek EC membership.

\subsection{North-North Integration: Canada in the CUSFTA}

The essence of the Canada-US Free Trade Agreement (CUSFTA), which came into effect on January 1, 1989, was the phased bilateral elimination of tariffs. In addition, a number of provisions reduced discrimination against bilateral foreign direct investment, including the extension of rights-of-establishment and national treatment. A range of prominent sectors, such as basic telecommunications, was effectively excluded from coverage under the investment liberalization provisions of the Agreement. Moreover, Canada's existing foreign investment screening procedures were left in place (Globerman and Walker 1993).

Nevertheless, the thrust of the investment provisions of the CUSFTA was clearly to expand the legal scope for bilateral direct investment. Moreover, the inclusion of a relatively robust dispute resolution procedure arguably reduced the risks of either government acting in a discriminatory manner towards investors from the other country. In terms of the first classification dimension of Figure 1 (i.e., the degree of environmental change resulting from the RIA) it seems reasonable to characterize the Canadian position as an intermediate one, with moderate changes resulting from the agreement. In this context, it should be remembered that bilateral trade between Canada and the US had been substantially liberalized well before the event studied here, through successive GATT rounds as well as special bilateral agreements such as the Auto Pact and the Defense Sharing Agreement. Regarding the 
locational advantages of Canada with respect to the US and the rest of the world, it is also reasonable to suggest an intermediate position. Hence, the position of Canada should be roughly at the center of Figure 1, which implies relatively moderate investment effects of the CUSFTA agreement. Does the empirical evidence support this hypothesis?

Bilateral trade between the United States and Canada has become relatively more important from 1988 onward which indicates that CUSFTA significantly liberalized the North American trade environment (see Globerman and Schwindt, 1996). It is, however, difficult to discern a consistent pattern in FDI flows between the two countries that would clearly be related to the CUSFTA.

Table 1 presents an overview of the Canadian foreign direct investment pattern between 1986 and 1995. Bilateral inward and outward direct investment refer to US direct investment inflows to Canada and Canadian direct investment outflows to the United States, respectively. Other inward and outward direct investment refers to non-US direct investment flows into Canada and Canadian direct investment flows to countries other than the United States. While there are substantial changes in FDI flows for individual years, the overall magnitude of bilateral direct investment was relatively stable (decreasing slightly in nominal terms) over the period 1988-1992. Substantial increases in the nominal value of inward direct investment from the United States emerged in 1993 and continued through 1995, while the nominal value of outward direct investment to the United States increased in 1994 and 1995 but only back to levels experienced in the mid-1980s. It is unlikely that these increases in investment flows are directly related to the CUSFTA, since they emerged in 1993, well after the implementation of CUSFTA, and coincided with a general boom in outward FDI flows from the US at that time. Furthermore, it is suggestive that a substantial decline in the value of the Canadian dollar began in 1992 following five years during which the Canadian dollar 
strengthened against its US counterpart. This decline in the value of the Canadian dollar may well have constituted an important motive for the increased US investments in the country.

Table 1

Inward and Outward Foreign Direct Investment for Canada (millions of Canadian dollars)*

\begin{tabular}{lcccc}
\hline & \multicolumn{2}{c}{ Bilateral } & \multicolumn{2}{c}{ Other } \\
Year & Inward & Outward & Inward & Outward \\
\hline & & & & \\
$\mathbf{1 9 8 3}$ & 29 & 1686 & 2438 & 1558 \\
$\mathbf{1 9 8 4}$ & 3196 & 3209 & 2960 & 1563 \\
$\mathbf{1 9 8 5}$ & -191 & 3144 & 1965 & 2130 \\
$\mathbf{1 9 8 6}$ & -743 & 3362 & 4607 & 1502 \\
$\mathbf{1 9 8 7}$ & 6028 & 7278 & 4632 & 4044 \\
$\mathbf{1 9 8 8}$ & 2052 & 2963 & 5899 & 1775 \\
$\mathbf{1 9 8 9}$ & 2091 & 3510 & 3850 & 1918 \\
$\mathbf{1 9 9 0}$ & 3246 & 2800 & 5917 & 2722 \\
$\mathbf{1 9 9 1}$ & 1961 & 1925 & 1187 & 4553 \\
$\mathbf{1 9 9 2}$ & 2719 & 1315 & 2673 & 3144 \\
$\mathbf{1 9 9 3}$ & 5308 & 968 & 1117 & 6522 \\
$\mathbf{1 9 9 4}$ & 7279 & 2456 & 960 & 4070 \\
$\mathbf{1 9 9 5}$ & 10229 & 3570 & 5122 & 2996 \\
\hline
\end{tabular}

Source: Statistics Canada, Canada's Balance of International Payments, Ottawa: Ministry of Industry, various issues

* Net flows including reinvested earnings accruing to direct investors.

Inward direct investment from countries other than the United States exhibits no consistent pattern over the period studied, although the largest inflows took place between 1988 and 1990, right after the implementation of the CUSFTA. Certainly there is no consistent evidence of any lasting diversion of foreign direct investment flows to Canada in response to CUSFTA. However, there is an interesting pattern in the development of Canadian outward direct investment to countries other than the United States. Until 1990, Canadian outward FDI was primarily directed to the US, but the early 1990s saw a significant decrease in the relative importance of the United States as a destination for Canadian outward direct investment. This decreasing share of outward FDI destined for the US is mirrored by an increasing share (beginning in 1991) going to EU member countries other than the United Kingdom, and an 
even more dramatically increasing share going to regions other than the EU, the United States and Japan. The profitable opportunities encouraging a redirection of Canadian direct investment outflows presumably had nothing to do with CUSFTA. However, CUSFTA may have played an important role in that it guaranteed access to the US market, so that available FDI resources could instead be utilized to establish Canadian presence in other markets.

As a complement to the flow data on FDI, Tables 2 and 3 present some recently published data on the gross product of US foreign affiliates in Canada and Canadian affiliates in the United States. Table 2 focuses on the role of foreign affiliates in the Canadian economy. The second column of the table measures the share of US majority-owned foreign affiliates in Canadian GDP. The US share has fallen from well over 11 percent in the early 1980s to about 8 percent in the early 1990 s. Coupled with the observation that bilateral trade with Canada has increased as a result of the CUSFTA, this suggests that regional integration has resulted in FDI becoming a relatively less important mode for US firms to serve the Canadian market.

\section{Table 2.}

Foreign Firms' Shares of Canadian GDP 1977-1993 (percent).

\begin{tabular}{ccc}
\hline Year & $\begin{array}{c}\text { US Affiliates in Canada } \\
\text { Canadian GDP }\end{array}$ & $\begin{array}{c}\text { All Foreign Firms in Canada/ } \\
\text { Canadian GDP }\end{array}$ \\
\hline & & \\
$\mathbf{1 9 7 7}$ & 13.8 & n.a. \\
$\mathbf{1 9 8 2}$ & 11.3 & n.a. \\
$\mathbf{1 9 8 3}$ & n.a. & 16.2 \\
$\mathbf{1 9 8 8}$ & n.a. & 15.6 \\
$\mathbf{1 9 8 9}$ & 9.5 & n.a. \\
$\mathbf{1 9 9 0}$ & 8.8 & 14.8 \\
$\mathbf{1 9 9 1}$ & 8.0 & n.a. \\
$\mathbf{1 9 9 2}$ & 7.9 & 14.3 \\
$\mathbf{1 9 9 3}$ & 8.2 & 15.1 \\
\hline
\end{tabular}

Sources: Mataloni and Goldberg (1994), Mataloni (1995), Fahim-Nader and Zeile (1995), Lipsey, Blomström, and Ramstetter (1995), and World Tables. 
In other words, there is some indication that trade has substituted for inward FDI from the US. Another indication of the same development is that Canada's share of US MNCs' foreign production has fallen significantly since the implementation of the CUSFTA. The ratio of US affiliates' production in Canada to the aggregate production of all US affiliates abroad fell from 16.3 percent in 1989 to 12.6 percent in 1993.

At the same time, it appears that Canada has become a somewhat more attractive investment location for outsiders. The last column of Table 2 shows that aggregate output share of all foreign affiliates has remained roughly constant, at about 15 percent of Canadian GDP, which indicates that other foreign investors have made up for the reduction of the US share of Canadian production.

Table 3 shows the data on foreign affiliates' shares of US output since 1988. It can be seen that the share of Canadian affiliates has fallen slightly since the start of the CUSFTA, from 0.7 percent in 1988 to 0.6 percent in 1994, while the aggregate share of all foreign firms has increased from 3.9 percent in 1988 to over 4.6 percent in $1993 .{ }^{7}$ The largest increases in the GDP shares of foreign firms seem to have taken place in connection with the implementation of the agreement, in 1988 and 1989. These data suggest a similar development as in the Canadian case: regional integration seems to have reduced the relative importance of intra-regional FDI, but stimulated inflows of FDI from the rest of the world. Comparing the Canadian and US experiences, it also appears that the effects on FDI are not evenly distributed. For Canada, the net result appears to be close to zero, where increased inter-regional inflows barely make up for reduced intra-regional investment. In the US case, there seems to be a positive net effect, with the increases in FDI inflows from the rest of the world dominating the reduced Canadian shares.

\footnotetext{
${ }^{7}$ Data are not available for the period before 1988 , which means that any conclusions regarding the relation between these changes and the establishment of CUSFTA should be treated with caution.
} 
Table 3

Foreign Firms' Shares of US GDP, 1988-1993 (percent).

\begin{tabular}{ccc}
\hline Year & $\begin{array}{c}\text { Canadian Affiliates in the US / } \\
\text { US GDP }\end{array}$ & $\begin{array}{c}\text { All Foreign Firms in the US } / \\
\text { US GDP }\end{array}$ \\
\hline & & \\
$\mathbf{1 9 8 8}$ & 0.72. & 3.89 \\
$\mathbf{1 9 8 9}$ & 0.69 & 4.25 \\
$\mathbf{1 9 9 0}$ & 0.69 & 4.31 \\
$\mathbf{1 9 9 1}$ & 0.69 & 4.50 \\
$\mathbf{1 9 9 2}$ & 0.57 & 4.42 \\
$\mathbf{1 9 9 3}$ & 0.65 & 4.58 \\
$\mathbf{1 9 9 4}$ & 0.62 & n.a. \\
\hline
\end{tabular}

Sources: See Table 2.

Hence, Canada offers a potentially instructive case study of the impacts of a RIA on foreign direct investment flows for a small open economy. Since economic theory makes no compelling case for a strong linkage between RIAs and FDI patterns for individual countries, and since the environmental change connected with the CUSFTA was not dramatic, it is hardly surprising that the pattern of overall foreign direct investment into and out of Canada over the past years does not suggest a strong and consistent influence of the agreement.

\subsection{North-South Integration: Mexico and NAFTA}

Shortly after the establishment of the CUSFTA, Canada and the United States initiated negotiations with Mexico about a possible southern expansion of the integration agreement. In December 1992, the three countries signed the North American Free Trade Agreement (NAFTA). This agreement, which came into effect on January 1, 1994, was the first formal regional integration agreement involving both a developing and developed countries. In essence, the NAFTA is an extended version of the CUSFTA. In addition to the trade and investment liberalization measures introduced already in the CUSFTA, the new treaty includes major advances in areas such as government procurement (where coverage is extended to services and construction) and intellectual property and investor's rights 
(introducing binding investor-state arbitration), as well as more stringent rules of origin (see e.g. Hufbauer and Schott 1993 for details).

The overall effects on Mexico of a free trade arrangement with Canada and the United States are expected to be significant, for several reasons. One important determinant is Mexico's geographical location. In the 1970s, many Mexicans considered it to be a drawback to be "so far from heaven and so close to the United States". Today, when regional trade and investment barriers have been reduced as a result of the NAFTA, the situation is different. The North American share of Mexican exports has increased from around 70 percent in the late 1980s to over 86 percent in 1995 (UN Trade Tapes). The value of Mexican exports more than quadrupled over the same period as a result of the increasing sales to North America, with the largest increases occurring between 1992 and 1995. The North American share of Mexican imports has also grown over this period, but not quite as dramatically

Another reason to expect positive implications of the free trade arrangement for the Mexican economy is related to the significant policy changes that have taken place in recent years. Traditionally, Mexico has been a closed economy. In the mid-1980s, however, important market-oriented reforms were introduced in several sectors, and the economy began to open up. As a consequence of the NAFTA, the reform process has been "locked in" and extended to other sectors, such as autos, textiles and apparel, finance, telecommunications, and land transportation (see Hufbauer and Schott 1993). The coincidence of policy reforms, distinct locational advantages in the form of cheap labor, and free access to a substantial part of the Canadian and US markets, is very likely to promote economic growth in Mexico. In terms of Figure 1, it is reasonable to position Mexico in area 1, which suggests that the effects on FDI should be significant. 
It is quite clear that foreign multinationals have noted and reacted on the recent changes in Mexico. As shown in Table 4 below, the inflows of FDI have risen significantly since the late 1980s, from less than USD 3 billion to nearly USD 8 billion in 1994.

Table 4

Foreign Direct Investment Flows into Mexico (USD million)

\begin{tabular}{lllllll}
\hline Year & $\mathbf{1 9 8 9}$ & $\mathbf{1 9 9 0}$ & $\mathbf{1 9 9 1}$ & $\mathbf{1 9 9 2}$ & $\mathbf{1 9 9 3}$ & $\mathbf{1 9 9 4}$ \\
\hline FDI inflows & 2,785 & 2,549 & 4,742 & 4,393 & 4,389 & 7,978 \\
\hline
\end{tabular}

Source: IMF, International Financial Statistics (various issues).

Since US multinationals dominate the FDI scene in Mexico it is relevant to look specifically at their responses to the NAFTA agreement. Table 5 suggest that US firms have expanded their presence in Mexico, but that much of the investment increase took place before the formal discussions about NAFTA began. The US FDI position in Mexico has not increased much since 1992, and the share of Mexico in total US investment abroad has actually declined during the past years. This indicates that outsiders account for the bulk of the recent inflows of FDI to Mexico. To some extent, these investments are probably directed to the local market, in response to the country's improving economic and institutional environment, but the investment flows are also likely to reflect some degree of investment diversion and investment creation. To the extent that Mexico has become a relatively more important supplier to the US market through trade creation or trade diversion, foreign multinationals are likely to respond by increasing their productive capacity in Mexico. 
Table 5

US Direct Investment Position in Mexico on a Historical-Cost Basis at Yearend, 1992-1995

(Million USD; percent of total US foreign direct investment position in parentheses)

\begin{tabular}{lccccc}
\hline Year & $\mathbf{1 9 8 7}$ & $\mathbf{1 9 9 2}$ & $\mathbf{1 9 9 3}$ & $\mathbf{1 9 9 4}$ & $\mathbf{1 9 9 5}$ \\
\hline US FDI Stock & 4,900 & 13,730 & 15,229 & 15,714 & 14,037 \\
& & $(2.73)$ & $(2.72)$ & $(2.53)$ & $(1.97)$ \\
\hline
\end{tabular}

Sources: Survey of Current Business, Vol. 75, No. 8, August 1995, and Lowe and Bargas (1996).

Moreover, the timing and character of the changes in the US investment position suggest that NAFTA has perhaps not been the main determinant of the upswing in US investments in Mexico. An equally important stimulus must have been the comprehensive reforms of the country's FDI regulation that commenced already in the mid-1980s and eventually culminated with the NAFTA. The Mexican regulatory framework for FDI, which dated back to 1973, was very restrictive and served as a disincentive for investment from abroad (Blomström 1989). In the backwash of the Mexican debt crisis, these regulations where changed dramatically in 1989 to attract foreigners to invest in Mexico. It appears that US investors responded quite strongly to this first round of reforms. A few years later, the investment regime was further liberalized through the NAFTA (see Gestrin and Rugman 1994 for details). Among others advances, the agreement established a clear, rules-based framework for the impartial treatment of FDI and placed strict limits on the use of performance requirements. It also established dispute-settlement mechanisms specifically designed to deal with investment issues. The US response was relatively mild this time, since many US firms were already in place (and because the agreement guaranteed their access to the Mexican market anyway), but investors from outside the region perceived Mexico as a much more attractive investment location than before.

When it comes to the effects of foreign investment in Mexico, there is some evidence that multinational firms have played an important role in opening up the country to foreign 
trade, by converting import-substituting industries into exporting (Blomström and Lipsey, 1993). The rapid expansion of the maquiladoras, where foreign firms play an important role, has also speeded up the trade liberalization process (Kagami 1996). However, the main contribution of the presence of foreign firms presumably comes from technology transfer and technology spillovers. The Mexican economy seems to have reached a level of development and skills where local firms are able to absorb some of the new technology that is imported and used by foreign multinational firms (see Kokko 1994 and Blomström, Lipsey and Zejan 1994). This means that the foreign owned multinationals operating in Mexico may well act as catalysts in bringing about the kind of dynamic growth effects that have been discussed in connection with the European Single Market program.

The experience of Mexico suggests that North-South integration may be greatly beneficial for the Southern partners, and illustrates some of the prerequisites for achieving these beneficial effects. Firstly, membership in the NAFTA coincided with other reforms that liberalized the institutional framework of the country. Hence, the RIA contributed to a very significant and positive environmental change. Secondly, Mexico possesses strong locational advantages with respect to its northern neighbors. These are made up of increasingly market oriented economic policies, geographical proximity, and cheap labor. Consequently, regional integration has been connected to significant increases in the inflows of foreign investment, in particular from countries outside the NAFTA region.

\subsection{South-South Integration: MERCOSUR}

Regional integration in the Southern Cone of the Western Hemisphere dates back to 1986, with a bilateral agreement between Argentina and Brazil, which stipulated the elimination of all trade barriers over a ten-year period. Five years later, in 1991, this agreement was extended under the Treaty of Asuncion, with the purpose of creating a Common Market in the region. 
The resulting agreement, known as MERCOSUR, also includes Paraguay and Uruguay as members. Intra-regional trade has gradually been liberalized since the early 1990 s, culminating in the establishment of a Customs Union on January 1, 1995. The MERCOSUR Customs Union stipulates free trade in (most) goods among the four member countries and a Common External Tariff (CET) for trade with third countries (see Laird 1995). The CET has 11 tariff levels varying from 0 to 20 percent, but some important product groups, like automobiles, telecommunications, and computer equipment, are excluded from the agreement. However, it should be noted that the integration process has not led to an across-the-board reduction of external tariffs for all countries. On the contrary, in several product groups, the CET is a compromise between countries with domestic import-substituting producers (who start out with high tariffs that are reduced as a result of integration) and countries without domestic production (where low initial trade barriers have been raised). In some cases, such as the region's automobile industry, it is even appropriate to talk about a general increase in the external trade barriers as a result of the integration process. In addition to the trade arrangements, a partially new investment regime has also been established to promote and protect investment in the MERCOSUR region (IDB 1996).

Looking at the reforms of the trade and investment rules in the MERCOSUR region during the past decade, it is clear that there have been significant changes, although it is uncertain how much of the reforms should be credited to the formal integration agreement. As noted above, there are areas where unilateral liberalization has been important, and other field where reforms are mainly related to multilateral initiatives, such as the GATT. Yet, in terms of the classification dimensions of Figure 1, it is clear that the environmental changes coinciding with the MERCOSUR process have been strong in all of the participating countries. Regarding the investment environment, it can be argued that Argentina and Brazil are the two countries with the strongest locational advantages, mainly thanks to abundant 
natural resources, relatively well developed industrial sectors, and large domestic market.

Considering the remaining barriers to inter-regional trade, these advantages apply in particular for production aiming at the regional market. Hence, at least for the cases of Argentina and Brazil, participation in the MERCOSUR should be classified in area 1 of Figure 1, which suggests that we should expect relatively significant investment effects for these two countries. The expected impact on the two remaining members, Paraguay and Uruguay, is more uncertain due to their smaller markets and weaker locational advantages.

The effects of the trade liberalization in the Southern Cone are evident from Table 6. During the first half of the 1990s, intra-MERCOSUR exports as a share of the region's total exports more than doubled, to reach nearly 20 percent in 1994.

Table 6

External Trade of MERCOSUR, 1988-1994 (Million USD and percent)

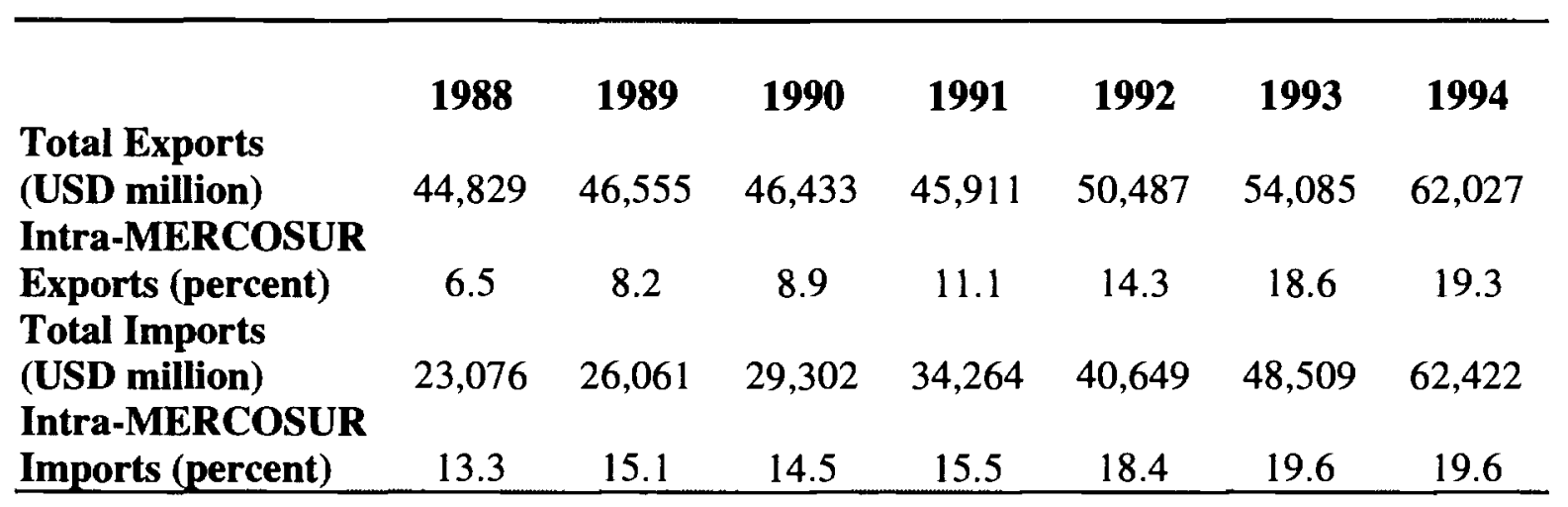

Source: Laird (1995)

Intra-regional imports as a share of total imports increased significantly as well, from 13.3 percent in 1988 to 19.6 percent in 1994 . It should be remembered that these changes refer to the period immediately before the establishment of the MERCOSUR Customs Union in 1995, and that the shares of intra-regional trade are likely to have increased further since then. Yet, the liberalization of intra-regional trade has been a gradual process, and most of the reforms in this area had already been completed by late 1994 . 
There is also a renewed interest in the MERCOSUR on the part of foreign investors. The inflow of foreign direct investment into the region more than tripled between 1989 and 1993, as shown in Table 7. As expected, Argentina and Brazil have been the favored localizations for FDI, while Uruguay and, particularly, Paraguay, have been lagging behind. Unfortunately, there are no aggregate data available to analyze FDI flows for the period after the establishment of the Customs Union in 1995.

Table 7

Foreign Direct Investment Flows into MERCOSUR Members (Million USD)

\begin{tabular}{ccccc}
\hline Year & Argentina & Brazil & Paraguay & Uruguay \\
\hline $\mathbf{1 9 8 9}$ & 1,028 & 1,131 & 12.8 & 37.7 \\
$\mathbf{1 9 9 0}$ & 1,836 & 989 & 76.3 & 38.6 \\
$\mathbf{1 9 9 1}$ & 2,439 & 1,103 & 83.1 & 30.3 \\
$\mathbf{1 9 9 2}$ & 4,179 & 2,061 & 42.0 & n.a. \\
$\mathbf{1 9 9 3}$ & 6,305 & 1,292 & 50.0 & 101.5 \\
$\mathbf{1 9 9 4}$ & n.a. & 3,072 & n.a. & 170.0 \\
\hline
\end{tabular}

Source: IMF: International Financial Statistics.

However, looking at home country data for the major foreign investor in the region, the United States, it appears that the real boom of FDI did not occur until after this event. Table 8 shows that in 1995 alone, the US stock of FDI in the region increased by more than 25 percent, which is significantly higher than the growth rate of US investment in the rest of the world. It should, therefore, be noted that we risk underestimating the investment responses to the MERCOSUR by restricting the analysis to the period for which data are available. 
Table 8

US Direct Investment Position in the MERCOSUR on a Historical-Cost Basis at Yearend, 1992-1995. (Million USD; shares of total US foreign direct investment position in parentheses.)

\begin{tabular}{lcccc}
\hline & $\mathbf{1 9 9 2}$ & $\mathbf{1 9 9 3}$ & $\mathbf{1 9 9 4}$ & $\mathbf{1 9 9 5}$ \\
\hline Argentina & 3,327 & 4,331 & 5,945 & 7,962 \\
& $(0.66)$ & $(0.77)$ & $(0.96)$ & $(1.12)$ \\
Brazil & 16,313 & 16,822 & 18,798 & 23,590 \\
& $(3.25)$ & $(3.01)$ & $(3.03)$ & $(3.31)$ \\
& & & & \\
MERCOSUR $^{\mathrm{a})}$ & 19,640 & 21,153 & 24,743 & 31,552 \\
& $(3.91)$ & $(3.78)$ & $(3.99)$ & $(4.43)$ \\
\hline
\end{tabular}

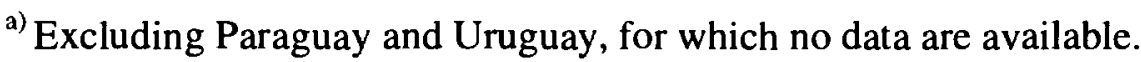

Source: Survey of Current Business, Vol. 75, No. 8, August 1995, and Lowe and Bargas (1996).

The aggregate data do not distinguish between intra- and inter-regional investment flows, but the significant increases in the investment position of the United States, shown in Table 8, suggest that a significant share of the inflows come from outside the MERCOSUR. It is also obvious that the increases in FDI flows have occurred at different times in the individual countries, which may indicate that foreign capital has been attracted by other factors than regional integration. This motivates a closer look at the individual countries.

Argentina registered the largest increases in FDI inflows before 1994, and there is reason to expect that much of this was unrelated to the regional integration process.

Chudnovsky, López, and Porta (1995) suggest three major explanations for the increases in foreign investment in Argentina since the early 1990s. The most important attraction for foreign investors was arguably Argentina's comprehensive privatization program, which opened several public service industries to foreign investment. Several public companies in the telecommunications and transportation sector were sold to foreign investors.

Another important determinant was the country's successful macroeconomic reforms, which managed to bring down public deficits, inflation, and interest rates, and ensured the convertibility of the currency. Unlike the present situation in Europe, where the members of 
the EU are obliged to fulfill certain macroeconomic "convergence criteria", economic integration in the form of MERCOSUR was not a motive for Argentinean macroeconomic stabilization. A third factor influencing foreign investors was the new wave of protectionism in the region's auto sector in the early 1990s. In 1991, Argentina introduced a system of quotas on imports of finished automobiles, which contributed to an increase in foreign investment inflows to the sector.

In the short run, it is likely that the effects of increased FDI inflows on the Argentinean economy will remain limited. For instance, the impact on the diversification and expansion of exports has been relatively modest so far, since a large part of the foreign investment has taken place in the nontradable sectors, in connection with the privatization of public services. In the long run, however, we should expect positive effects of these investment, since the efficiency of public services is likely to improve and strengthen the country's international competitiveness. In the auto sector, by contrast, it is apparent that the recent FDI inflows have contributed significantly to technology transfer and modernization, but the long-run effects on the country's competitiveness and welfare remain questionable. As in other cases of import substitution, protectionism distorts the allocation of scarce resources and allows local producers to operate less efficiently than foreign competitors.

The foreign investment in Brazil has fluctuated widely during the past years, and the inflows of FDI have fallen well short of those to Argentina, although the Brazilian market is about four times larger. One reason is that market-oriented reforms were introduced later and macroeconomic stabilization was achieved later in Brazil than in the other countries in the region. Consequently, the positive prospects connected with regional integration were tempered by an unpredictable macroeconomic environment. However, the recent years have witnessed successful reforms and stabilization in Brazil as well and the inflows of FDI have increased markedly. For instance, Brazil replaced Argentina as the favored MERCOSUR 
location for US direct investment in 1994 and 1995 (see Table 8). The strong locational advantages of Brazil - in terms of its large market and supply of labor and natural resources suggest that we should expect substantial inflows of foreign investment in the medium run, assuming that the country's macroeconomic environment remains stable.

The experiences of the two smaller countries in the region, Paraguay and Uruguay, are mixed. While the flows of FDI to Uruguay seem to have increased, there is no clear trend for Paraguay. Uruguay is arguably more attractive for foreign investors because of its geographical location between Brazil and Argentina, while the locational advantages of Paraguay are weaker. In both cases, foreign investment can be expected to be directed to industries where economies of scale are not important - industries relying on scale economies are more likely to locate in either Argentina or Brazil, where they can benefit from proximity to larger consumer markets. However, neither Uruguay nor Paraguay is likely to be influenced greatly by static investment effects. Instead, their benefits of economic integration are likely to derive from possible dynamic effects, that lead to growth and increased demand for their exports in the entire MERCOSUR region. It is also possible that economic integration will have a stabilizing impact on the political and macroeconomic environment in both countries, in the sense that radical policy changes are less likely because of the commitments to the neighboring countries.

Given that the MERCOSUR Customs Union was not established until 1995, it is obvious that it is too early to accurately describe even the static effects of that specific RIA on foreign investment. Yet, less ambitious forms of regional integration have been pursued by the MERCOSUR countries since the mid-1980s, so that much of the intra-regional trade had been liberalized in 1994, and it is possible to draw some tentative conclusions from the region's experience to date. The following generalizations are suggested by the analysis above. 
First, macroeconomic stability is likely to be a more important determinant of FDI inflows than is regional integration. Both the Argentinean and Brazilian experiences illustrate that foreign investors have responded stronger to successful stabilization programs than to the early stages of the MERCOSUR project. Second, comprehensive integration, as in the case of the MERCOSUR Customs Union, may stimulate significant investment responses. In our data, this has mainly been illustrated by the changes in the US investment position in the region between 1994 and 1995, but there are indications that investors from other countries have also reacted strongly, as discussed above. Third, the inflows of FDI to the region are not likely to be distributed equally to all participating countries. Argentina and Brazil possess relatively strong locational advantages and will also be the main beneficiaries of increased FDI inflows in the short to medium run. Finally, as illustrated by the development in the MERCOSUR auto sector, it is not evident that the welfare effects of all FDI increases will be positive. To the extent that regional integration contributes to increased distortions, e.g. in the form of higher tariff barriers or market sharing agreements between oligopolistic producers, it is possible that the resulting inefficient allocation of resources outweighs the various benefits of FDI inflows, such as technology spillovers.

\section{Summary and Conclusions}

The relation between regional integration agreements and FDI is neither self-evident nor straightforward, but the discussion in the first part of the paper provided a rough working hypothesis for empirical analysis, summarized in Figure 1: the stronger the environmental change connected with regional integration and the stronger the locational advantages of the individual country or industry, the more likely it is that integration agreement will lead to inflows of FDI from the outside as well as from the rest of the integrating region. 
The empirical evidence in the second part of the paper provided some support for this rough hypothesis, although the cases also highlighted some of the cross-country differences in the investment effects of regional integration. The first case focused on the Canadian participation in the CUSFTA, and illustrated a situation where the RIA did not appear to cause any radical changes in the inflows of FDI to the country in question. The main reasons for the moderate impact of the CUSFTA are probably that the environmental change connected with the agreement was not dramatic (since trade between Canada and the US was already relatively to start with) and that there was already considerably cross-investment between the two countries. The relatively modest investment response to this specific agreement may well be a general characteristic of many North-North agreements, where the trade and investment regimes are relatively open and markets are de facto integrated already before formal integration agreement.

The second case examined the impact of the NAFTA agreement on foreign investment in Mexico, and suggested that this specific agreement has had a profound impact on the inflows of FDI. The establishment of the NAFTA coincided with and deepened other reforms that liberalized the institutional framework of the country. Hence, the agreement contributed to very significant and positive environmental changes: an added bonus is that these are likely to be perceived as more permanent improvements in the investment environment than purely domestic reforms. Thanks to its increasingly market oriented economic policies, geographical proximity, and supply of cheap labor, Mexico also possesses strong locational advantages with respect to its northern neighbors. Consequently, regional integration has created new commercial opportunities for domestic and foreign investors, in the domestic Mexican market as well as in the US and Canadian markets. The response has been a significant increase in the inflows of FDI, in particular from countries outside the NAFTA region. The Mexican experience may capture some general characteristics of North-South agreements, primarily 
related to the potential for improved policy credibility and gains from guaranteed access to large northern markets.

The third case examined the impact of regional integration in the Southern Cone, involving Argentina, Brazil, Paraguay, and Uruguay. Although the MERCOSUR Customs Union was not formally established until the beginning of 1995, a gradual liberalization of intra-regional trade commenced in 1991, and most internal trade barriers had been removed by 1995. The available evidence, although patchy, show that a strong investment expansion has coincided with this integration process, and it is reasonable to assume that the continuing integration process may stimulate further significant investment responses. However, the inflows of FDI are not likely to be distributed equally to all participating countries. The two countries with the strongest locational advantages, Argentina and Brazil have been the main beneficiaries of increased FDI inflows in the short to medium run. The experience of the MERCOSUR region also suggests an important caveat that may be relevant for many other instances of South-South RIAs. Macroeconomic stability may have been a more important determinant of FDI inflows to both Argentina and Brazil than is regional integration: both the Argentinean and Brazilian experiences can be interpreted as responses to successful stabilization programs rather than consequences of regional integration.

This brings us to some of the limitations of the present paper and suggestions for further research. The analysis has focused on the impact of RIAs on FDI flows, but the more general welfare effects have not been discussed in detail, neither for the integrating region nor for the world at large (see Fernandez 1997 for an analysis of some related welfare aspects of RIAs). Moreover, we have concentrated on ownership issues, interpreting FDI flows as changes in the ownership of production factors. Future research should of course consider welfare effects in closer detail, and also take into account factors that determine production location rather than ownership issues alone (see Puga and Venables 1996 for a formal 
treatment of location and welfare issues). Regarding the empirical cases, the discussion has

focused on entire countries, and individual sectors and industries have seldom been addressed.

However, the conceptual framework presented in the paper suggests that the impact of RIAs is

likely to differ between countries and industries, and more detailed sectoral studies are clearly

called for.

\section{REFERENCES}

Balasubramanyam, V.N. and Greenaway, D. (1992), "Economic Integration and Foreign Direct Investment: Japanese Investment in the EC", Journal of Common Market Studies, Vol. 30, pp. 175-93.

Baldwin, R. (1989), "The Growth Effects of 1992", Economic Policy, Vol. 9, pp. 247-81.

Behrman, J.N. (1972), The Role of International Companies in Latin American Integration. Lexington, Mass.: Lexington Books.

Blomström, M. (1989), Foreign Investment and Spillovers. London and New York: Routledge.

Blomström, M. and Kokko, A. (1997), 'The Impact of Foreign Investment on Host Countries: A Review of the Evidence", Working Paper, The World Bank.

Blomström, M. and Lipsey, R.E. (1993), "Foreign Firms and Structural Adjustment in Latin America. Lessons from the Debt Crisis", in G. Hansson (ed.), Trade, Growth and Development. The Role of Politics and Institutions. London and New York: Routledge.

Blomström, M., Lipsey R.E. and M. Zejan (1994), "What Explains the Growth of Developing Countries?" in W.J. Baumol, R.R. Nelson, and E.N. Wolff (eds.), Convergence of Productivity. Cross-National Studies and Historical Evidence. Oxford and New York: Oxford University Press.

Brecher, R.A. and C.F. Díaz Alejandro (1977), "Tariffs, Foreign Capital and Immiserizing Growth", Journal of International Economics, Vol. 7, pp. 317-22.

Buckley, P. and M. Casson (1976), The Future of the Multinational Enterprise. London: Macmillan.

Bulmer-Thomas, V. (1982) "The Central American Common Market", in A. El-Agraa (ed.), International Economic Integration. London: Macmillan.

Caves, R.E. (1996), Multinational Enterprise and Economic Analysis. Second edition, Cambridge: Cambridge University Press.

Chudnovsky, D., A. López, and F. Porta (1995), "New Foreign Direct Investment in Argentina: Privatization, the Domestic Market, and Regional Integration", in M.R. Agosin (ed.), Foreign Direct Investment in Latin America. Washington: InterAmerican Development Bank.

Chudnovsky, D., A. López, and F. Porta (1996), "Intra-Industry Trade and Regional Integration: The Case of the Auto Industry in Argentina", in M.J. Lord (ed.), Latin American Trade in Manufactures: A Handbook of Regional and Country Case Studies. Ann Arbor: University of Michigan Press.

Dunning, J.H. (1977), 'Trade, Location of Economic Activity and the MNE: A Search for An Eclectic Approach", in B. Ohlin, P-O Hesselborn and P.M. Wijkman, (eds.), The International Allocation of Economic Activity. London: Macmillan. 
Dunning, J.H. (1992), "Transatlantic Foreign Direct Investment and the European Economic Community", International Economic Journal, Vol. 6, pp. 59-81.

Emerson, M. et al. (1989), The Economics of 1992. Oxford: Oxford University Press.

Fahim-Nader, M. and W.J. Zeile (1995), "Foreign Direct Investment in the United States: New Investment in 1994 and Affiliate Operations in 1993", Survey of Current Business, Vol. 75, pp. 57-81.

Fernandez, R. (1997), "Returns from Regionalism: An Evaluation of Non-Traditional Gains from RTAs", mimeo, Washington, D.C.: IECIT, World Bank, February.

Franko, L.G. (1976), The European Multinationals: A Renewed Challenge to American and British Big Business. Stamford, CT: Greylock.

Gestrin, M. and A.M. Rugman, (1994), "The North American Free Trade Agreement and Foreign Direct Investment", Transnational Corporations, Vol. 3, pp. 77-95.

Globerman, S. and R. Schwindt (1996), "International Trade Agreements and Foreign Direct Investment in the Agri-Industrial Sector", report prepared for Agriculture and AgriFood Canada, mimeo, May.

Globerman, S. and M. Walker, (1993), Assessing NAFTA: A Trinational Analysis. Vancouver: The Fraser Institute.

Grant, R. (1983), "The Impact of EEC Membership upon the UK Industrial Performance", in R. Jenkins (ed.), Britain and the EEC. Proceedings of Section F (Economics) of the British Association for the Advancement of Science. London: Macmillan.

Hufbauer, G.C. and Schott, J.J., assisted by Dunnigan, R. and Clark, D. (1993), NAFTA. An Assessment. Revised Edition. Washington, D.C.: Institute for International Economics.

IDB (1996), Regimenes de inversion extranjera en los paises de las Americas. Estudio comparativo, Washington D.C.: Banco Interamericano de Desarrollo.

IMF (various issues), International Financial Statistics, Washington, D.C.: International Monetary Fund.

Kagami, M. (1996), "Maquiladoras and Foreign Direct Investment in Mexico", in M.J. Lord (ed.), Latin American Trade in Manufactures: A Handbook of Regional and Country Case Studies. Ann Arbor: University of Michigan Press.

Kindleberger, C.P. (1966), 'European Integration and the International Corporation", Columbia Journal of World Business, Vol. 1, pp. 65-73.

Kokko, A. (1994), 'Technology, Market Characteristics, and Spillover", Journal of Development Economics, Vol. 43, pp. 279-93.

Laird, S. (1995), "MERCOSUR Trade Policy: Towards Greater Integration", mimeo, Geneva: World Trade Organization.

Lipsey, R.E. (1990), "American Firms Facing Europe: 1992", in M. Feldstein and Y. Kosai (eds.), US-Japan Economic Forum, Cambridge: NBER.

Lipsey, R.E., Blomström, M. and E. Ramstetter (1995), "Internationalized Production in World Output", NBER Working Paper No. 5385.

Lowe, J.H. and Bargas, S.E. (1996), "Direct Investment Positions on a Historical-Cost Basis", Survey of Current Business, Vol. 76, pp. 45-55.

Mataloni, R.J. Jr. (1995), "U.S. Multinational Companies: Operations in 1993", Survey of Current Business, Vol. 75, pp. 31-51.

Mataloni , R.J. Jr. and Goldberg, L. (1994), "Gross Product of U.S. Multinational Corporations, 1977-91", Survey of Current Business, Vol. 74, pp. 42-63.

Mayes, D.G. (1983), "EC Trade Effects and Factor Mobility", in A.M. El-Agraa (ed.), Britain Within the European Community: The Way Forward. London: Macmillan

Molle, W. and Morsink, R. (1991), 'Intra-European Direct Investment", in B. Bürgenmeier and J.L. Muccielli (eds.), Multinationals and Europe 1992: Strategies for the Future, London and New York: Rourledge. 
Mundell, R.A. (1957), "International Trade and Factor Mobility", American Economic Review, Vol. 47, pp. 321-35.

Mytelka, L.K. (1979), Regional Development in a Global Economy: The Multinational Corporation, Technology, and Andean Integration. New Haven: Yale University Press.

O'Farrell, P.N. (1983), "Ireland", in L.H. Klaassen and W.T.M. Molle (eds.), Industrial Mobility and Migration in the European Community. Aldershot: Gower.

Pelkmans, J. (1984), Market Integration in the European Community. The Hague: Martinus Nijhoff.

Puga, D. and A. Venables (1996), "Trading Arrangements and Industrial Development", mimeo, Washington, D.C.: IECIT, World Bank, November.

Smith, A. (1992), "Measuring the Effects of '1992'”, in D. Dyker (ed.), The European Economy. London and New York: Longman.

Smith, A. and A. Venables (1988), "Completing the Internal Market in the European Community: Some Industry Simulations", European Economic Review, Vol.32, pp. 1501-25.

Statistics Canada (various issues), Canada's Balance of International Payments. Ottawa: Ministry of Industry.

Stevens, G.V.G. and R.E. Lipsey, (1992), "Interactions between Domestic and Foreign Investment, Journal of International Money Finance, Vol. 11, pp. 40-62.

Thomsen, S. and P. Nicolaides (1991), The Evolution of Japanese Direct Investment in Europe. New York and London: Harvester Wheatsheaf.

Winters, L. A. (1996), 'Lebanon's Euro-Mediterranean Agreement: Possible Dynamic Benefits", paper prepared for Lebanese Center for Policy Studies' Conference on "Lebanese-EU Relations", Beirut, July 1-2, mimeo.

World Bank (various issues) World Tables. Baltimore and London: Johns Hopkins University Press for the World Bank.

Yannopoulos, G.N. (1990), "Foreign Direct Investment and European Integration: The Evidence from the Formative Years of the European Community", Journal of Common Market Studies, Vol. 28, pp. 235-59. 